The two main lines of research being established in the Physics Department (head of the Department, Mr. E. G. Dunstan) are the study of the Earth's magnetic field, which has developed out of studies carried out in Nigeria during the International Geophysical Year, and the study of atmospheric electricity, for which the tropics are especially suited.

In the Geography Department, under Mr. G. Dalton, the main topics of study at present are elimatology and land-use surveys. A somewhat related topic under study in the Department of Applied Science, with Mr. B. Pescod, is the nature of lateritic soils, especially with regard to the application of cement stabilization techniques.

The conferment of university college status leads to the hope that Fourah Bay College will attract research workers in science wishing to work in the tropics. From the point of view of the biological field worker, for example, Freetown offers a unique annual rainfall regime on the coast of West Africa, and a range of varied habitats within relatively easy reach.

\title{
OBITUARIES
}

\section{Academician I. V. Kurchatov}

THe death of I. V. Kurchatov on February 7 is a severe loss to physics, particularly in the U.S.S.R. As director of the Atomic Energy Institute of the Academy of Sciences and an outstanding leader in atomic energy research of all varieties, he played a leading part in determining Russian atomic energy policy. Much credit must go to him for the rapid post-war developments of the Russian programme, and he received many honours from the Soviet Government for his work. He was a member of the Praesidium of the Academy of Sciences and a deputy to the Supreme Soviet of the U.S.S.R.

Born in 1903 in Eastern Russia, Igor Vasilevitch Kurchatov graduated at the University of the Crimea in 1923 and started research at the Leningrad Physico-Technical Institute, then under the direction of A. Joffe, in 1925. Up to 1933 he carried out experimental and theoretical studies of dielectrics, particularly on the properties of Rochelle salt. $\mathrm{He}$ was the first to give a mathematical theory of ferroelectricity, basing his approach on the LangevinWeiss theory of ferromagnetism. His many researches on this subject were summarized in a short book published in 1933. Other work at this time included studies of dielectric breakdown.

Kurchatov's nuclear physics work began in 1933 , and in 1938 he was made director of nuclear physics research at the Leningrad Institute, where he and his collaborators conducted many pioneer researches into nuclear reactions produced by neutrons. His work on the activities induced in bromine, together with the results obtained by Fermi's group, led to the first identification of a long-lived nuclear isomer. Other work included detailed studies of the ${ }^{10} \mathrm{~B}(n, \alpha)$ reaction, and the scattering and absorption of neutrons in water, paraffin and other moderating media. His group was thus exceptionally well placed to follow up the discovery of nuclear fission in 1939, and in 1941 he published an authoritative paper surveying various possible ways of developing a chain-reacting system based on thermal neutron fission of heavy elements.

The Atomic Energy Institute was started towards the end of the Second World War. It is a large establishment, occupying several hundred acres on the outskirts of Moscow, devoted to fundamental research on atomic energy. The wide scope of research there was revealed at the first Geneva Conference on the Peaceful Uses of Atomic Energy in 1955 . From his public statement in 1958 claiming Russian priority in the development of a practical military form of the hydrogen bomb, it appears that
Kurchatov played a leading part in military as well as civil applications of atomic energy.

In recent years, the problems of plasma physics and controlled thermonuclear reactions formed a significant part of the work at Kurchatov's institute. Studies of magnetic confinement of plasma were vigorously pursued there by a group led by a pre-war Leningrad colleague, L. A. Artsimovitch. The first public account of this work was given by Kurchatov at Harwell in May 1956, in a lecture remarkable not only for its content but also for the bizarre circum. stance that his audience was at that time keeping work in this field secret. In 1958 he gave the first account of further work in his institute on this subject, including the building of the enormous magnetic trap installation Ogra.

Kurchatov's career is largely synonymous with the development of atomic energy in the U.S.S.R., and although he died before many important aspects have come to fruition, the Russian achievements in this field, together with the size and vitality of his research institute, stand as an impressive testimony to his abilities. He believed in the value of international collaboration in science, and gave a most friendly reception to visitors from England to his institute.

His high scientific abilities, integrity and personal charm greatly impressed all who met him.

\section{R. S. PEASE \\ B. F. J. SCHONLAND}

\section{Prof. H. G. Robinson, C.B.E.}

Henry Goland Robinson, first professor of agriculture in the University of Nottingham, for many years principal of the Midland Agricultural College and later director of the University of Nottingham School of Agriculture, died on February 20 at his home in Wellington, Shropshire, aged sixtythree. A graduate of the University of Durham, he held appointments at Cockle Park and the then University College of Reading, before becoming senior lecturer in agriculture at the Midland Agricultural College, Sutton Bonington, in 1925. Ten years later he was appointed principal of the Midland Agricultural College, and led the developments which culminated in its union with the then University College of Nottingham as the Faculty of Agriculture and Horticulture. Robinson became the first professor of agriculture and dean of the Faculty.

Robinson will long be remembered for his work for the Midland Agricultural College and the University of Nottingham School of Agriculture, and for his 
services to agricultural education and farming in Britain, for at one time he was a member of thirtynine committees, including the Nottinghamshire War Agricultural Executive Committee and several of its sub-committees. He lectured on aspects of agriculture throughout Britain and was a keen advocate of good husbandry. For his services to agricultural education he was appointed a Commander of the Order of the British Empire in 1955, and he was elected emeritus professor of agriculture in the University of Nottingham on his retirement, through illness, in 1954. J. D. IVINS

\section{NEWS and VIEWS}

\section{First Award of the Vetlesen Prize :}

Prof. Maurice Ewing

Dr. Maurice Ewing, director of the Lamont Geological Observatory, Columbia University, New York, has been awarded the Vetlesen Prize for outstanding achievement in the earth sciences. This is the first award of this Prize, which consists of a gold medal, 25,000 dollars and support of publication of the recipient's scientific papers. Dr. Ewing, professor of geology at Columbia, and a native of Lockney, Texas, is known internationally for his work in the Earth sciences, and among the previous honours he has received are the Day Medal of the Geological Society of America ; the Agassiz Medal of the U.S. National Academy of Sciences; and the William Bowie Medal of the American Geophysical Union. Dr. Ewing, who has been a teacher of both physics and geology, considers himself primarily a physicist who applies fundamental science-physics, chemistry and mathematics-to the study of the Earth.

The Vetlesen Prize was established this year at Columbia University by the G. Unger Vetlesen Foundation for "achievement resulting in a clearer understanding of the earth, its history or its relation to the universe". Like the Nobel Prizes established more than fifty years ago, the Vetlesen Prize recognizes no national boundaries, and any person in any country may be nominated for it. The Nobel Prizes, set up when the Earth sciences were of secondary importance, cover the fields of physies, chemistry, medicine, literature and peace. Funds for both prizes have been provided by Scandinavians. Alfred B. Nobel was a Swedish munitions maker. Georg Unger Vetlesen, a shipping executive, was a native of Norway who became a United States citizen during the Second World War. He established the foundation bearing his name shortly before his death in 1955 . The Vetlesen Prize is to be awarded every two years provided a worthy candidate is presented.

\section{The British Museum (Natural History) : Sir Gavin de Beer, F.R.S.}

THE retirement of Sir Gavin de Beer from the directorship of the British Museum (Natural History) at the end of April this year ends one of the most memorable decades in the history of this institution. He took office at a time when the Museum was still suffering from the effects of the War and during his tenure has succeeded in carrying out an ambitious programme of reconstruction and extension of the Museum facilities and also helped to restore its international prestige. The building of the North Block, with Lecture Theatre, Map Room, General Library and Reading Room, is one of the more obvious additions; but the Mammal Building, extension of the Whale Hall, completion of the Entomological Block, and the new Botanical Gallery, with Cryptogamic Herbarium and laboratories, have all greatly increased the amenities and facilities for scientific study. The Mammal Balconies now include exhibits on the functional morphology of mammals, and the Central Hall has been re-organized to accommodate the big pachyderms and a completely new set of exhibits on evolution which were specially prepared in connexion with the Darwin-Wallace Centenary.

Sir Gavin has carried out investigations on Archoeopteryx, and the evolution of Ratites, apart from many historical studies of special interest to the Museum, including the Darwin manuscripts and note-books; Sir Hans Sloane and the British Museum; the Banks correspondence; and he initiated the Historical Series in the Museum Bulletin. Among his other publications a "Short Guide to the Museum", "Scientific Research in the Museum", and a "Handbook to Evolution" were issued for the use of visitors. It was a fortunate coincidence that the Darwin-Wallace Centenary should have occurred during the term of office of one of the greatest authorities on evolution and he took a leading part in the celebrations of that event. In addition, Sir Gavin was president of the fifteenth International Congress of Zoology, held in London during 1958, which attracted by far the largest attendance on record. He was also president of Section D (Zoology) at the meeting of the British Association in Oxford in 1954.

Sir Gavin de Beer's successor will be Dr. T. C. S. Morrison-Scott, director of the Science Museum. Dr. Morrison-Scott was formerly on the staff of the British Museum (Natural History), where he worked mainly in the Mammal Department (see Nature, 177, $1061 ; 1956)$.

\section{Laboratory of the Government Chemist :}

Mr. E. H. Nurse, C.B.E.

ON March 31, Mr. E. H. Nurse will retire as acting Government Chemist from what was until recently the Department of the Government Chemist. Mr. Nurse has spent the whole of his career in this Department, which he joined in 1915, following graduation with first-class honours in chemistry from the University of London. During the First World War he served for two years with the Royal Naval Air Service and the Royal Air Force as a hydrogen officer with airships. On the re-organization of the Scientific Civil Service in 1946 he became a principal scientific officer, and he was promoted to the grade of senior principal scientific officer in 1948. $\mathrm{He}$ has represented the Department on a number of scientific and technical committees and has been particularly concerned, both at headquarters and the subsidiary laboratories maintained at certain ports, with chemical work in connexion with revenue duties of Customs and Excise. He was appointed Deputy Government Chemist in 1954 on the retirement of Dr. J. R. Nicholls, and on the death of Dr. G. M. Bennett, in February 1959, he became acting Government Chemist. During his period as head of the 